\title{
ВІДГОДІВЕЛЬНІ ЯКОСТІ ІМУНОКАСТРОВАНИХ ТА НЕКАСТРОВАНИХ СВИНОК
}

\author{
Андрєєва Діана Миколаївна \\ аспірант спец. 204 «ТВППТ » \\ Миколаївський національний аграрний університет \\ ORCID ID: 0000-0003-4572-0856 \\ Email: andreevasvk@gmail.com
}

Повод Микола Григорович доктор сільськогосподарських наук, профресор Сумський національний аграрний університет ORCID ID: 0000-0001-9272-9672/ W-1565-2018

Email: nic.pov@ukr.net

\begin{abstract}
У статті представлено результати досліджень відгодівельних якостей імунокастрованих та некастрованих свинок отриманих від помісних свиноматок ірландського ландраса та ірландського йоркшира і кнурів синтетичної лінії Маxgro, в умовах ТОВ «НВП «Глобинський свинокомплекс» чеху відгодівлі №3. Для виконання дослідження було сфоормовано дві групи свинок, середня жива маса яких знаходилась в межах 25,68 - 25,82 ке, з похибкою 0,30-0,26 ке. Встановлено, що імунокастровані свинки на відмінну від некастрованих свинок в період відгодівлі мали більшу середню живу масу при знятті з відгодівлі на 4,96\%. Характеризувалися вищими на 6,65\% та 6,64\% показниками абсолютного та середньодобового приросту. Відносний приріст був вищим у імунокастрованих свинок на 4,20\% ( $p<0,001)$. Імунокастровані свинки щодоби на 3,54\% споживали більше корму, що спричинило досягнення їх живої маси 120 ке на 3,89 \% швидше, в той час як оплата корму приростами була кращою на 2,39\% в порівнянні з некастрованими свинками. Індекс комплексної оцінки відгодівельних якостей імунокастрованих тварин був вищим на 4,4 бали або на 11,8\% порівняно з з їх некастрованими аналогами. За допомогою однофракторного дисперсійного аналізу було встановлено силу впливу типу кастрації свинок на їх відгодівельні показники. Визначено значний вірогідний вплив типу кастрації свинок на такі відгодівельні показники як середня жива маса при зняті з відгодівлі на рівні 7,53\%, абсолютний приріст на 10,92\% середньодобовий приріст на 10,91\% та вік досягнення живої маси 120 кг на рівні 7,09\%. Сила впливу типу кастрації свинок на відносний приріст склала всього 2,71\%. Результати досліджень засвідчили, що використання імунної кастрації свинок має значний вплив та підвищує їх відгодівельні показники.
\end{abstract}

Ключові слова: свинка, приріст, імунна кастрація, відгодівля, конверсія корму, споживання корму.

DOI: https://doi.org/10.32845/bsnau.lvst.2020.3.3

Постановка проблеми. Вирішення проблеми тваринного білку в харчуванні людини не можливе без розвитку галузі свинарства. На сьогоднішній день ця галузь інтенсивно розвивається за рахунок індустріалізації та концентрації виробництва. 3 цією метою в свинарстві використовується інтенсивні генотипи свиней, повноцінні та збалансовані комбікорми, створюються комфортні умови утримання для тварин. В жорстких ринкових умовах для підвищення конкурентоспроможності виробники свинини використовують додаткові можливості організму свиней. Однією з таких можливостей $\epsilon$ кастрація свинок, яка змінює гормональний статус їх організму та підвищує продуктивність. Тому в нашій роботі проведено вивчення відгодівельних показників некастрованих та імунокастрованих свинок.

Аналіз останніх досліджень. Основою більшості опублікованих досліджень $є$ імунізація тварини проти репродуктивного гормону у власній системі, яка називається $\mathrm{GnRH}$, або вивільняючий гормон гонадотропіну. Це дуже мала молекула, яка виробляється та виділяється ендокринною (гормональною) системою. Цей гормон виробляється і виділяється біля основи мозку і розпочинає репродуктивний процес, ініціюючи вивільнення інших репродуктивних гормонів, які викликають активність (вироблення та ріст гормонів) у чоловічих сім'яниках або жіночих яєчниках [8]. Імунокастрація використовує природну імунну систему тварини для досягнення ефектів кастрації. Вакцина містить фізіологічно неактивний аналог $\mathrm{GnRH}$, ковалентно кон'югований з імуногенним білком-но-

сієм. Аналог не має гормональної активності, але містить необхідні епітопи для стимулювання ефективної реакції антитіл проти $\mathrm{GnRH}$ та блокує стимуляцію осі гіпоталамус-гіпофріз-гонади. В результаті чого утворення стероїдних гормональних залоз утруднене, що призводить до регресу репродуктивних органів та деяких індукованих метаболічних змін, що в кінцевому рахунку викликає зміни у поведінці (зниження агресивності, підвищення апетиту і споживання корму) та показниках росту [4].

В попередніх дослідженнях нами було проведено порівняльну характеристику відгодівельних якостей імунологічних та хірургічних кастратів самців за різного типу годівлі та передзабійної маси. В результаті було виявлено, що як за сухого так і за рідкого типу годівлі імунокастровані кнурці споживали більше корму, мали вищу інтенсивність росту, раніше досягли живої маси 100 та 120 кг, при цьому мали кращу конверсію корму порівняно з хірургічно кастрованими аналогами. [2]

M. Skrlep та B. Segula [5], вивчали вплив імунокастрації (вакцинація проти вивільняючого гормону гонадотропіну 3 використанням вакцини Improvac) на ефективність росту у словенських м'ясних свиней, в результаті чого було підтверджено переваги імунокастрованих кнурців порівняно з хірургічними кастратами у рості, та головним чином у ефеективності використання кормів.

За даними N. Batorek [6] після другої вакцинації імунокастровані кнурці їдять набагато більше некастрованих 
кнурців $(\theta=2,1)$, що призводить до значного підвищення швидкості росту порівняно з некастрованими та хірургічно кастрованими кнурцями ( $\theta=1,1$ та $\theta=1,4$ відповідно). За період відгодівлі, коефріцієнт їх конверсії кормів був вищий порівняно з некастрованими кнурцями $(\theta=0,6)$ і набагато нижчим, ніж у хірургічно кастрованих самців $(\theta=-1,3)$, хоч і встановлено помірно швидший ріст порівняно з обома групами тварин $(\theta$ $=0,6$ і $\theta=0,2$ відповідно.

В дослідженях Yongqiang Xue [7] при порівнянні показників розвитку статевих залоз, росту свиней, та якості м'яса у сухуайських некастрованих, імунокастрованих та хірургічно кастрованих самок свиней. В результаті не встановлено суттєвих відмінностей у рості серед некастрованих, імунокастрованих та хірургічно кастрованих свинок, за винятком імунокастрованих свинкок яким двічі вводили вакцину проти вивільняючого гормону гонадотропіну, які мали краще середньодобове споживання корму $(p<0,05)$. Доведено, що імунокастрація успішно гальмує розвиток статевих залоз і не має негативних наслідків для показників росту самок сухуайської породи свиней.

Актуальність. Використання імунокастрації свиней зростає, щомісяця у всьому світі вакцинують приблизно 1,3 мільйона свиней [3]. В Україні деякі потужні виробники свинини застосовують імунну кастрацію для кнурців як альтернатива хірургічній кастрації. Проте більша частина господарств не приймають технологію імунної кастрації свиней, оскільки вважають що такий спосіб кастрації може негативно впливати на якість м'яса та в подальшому на організм людини. На наш погляд ці підстави не є актуальними, тому що в європейських країнах дуже ретельно вивчено всі ці питання, і експериментально доведено що використання імунної кастрації кнурців не має негативного впливу як на якість м'яса так і на організм людини. Проте як в Україні так і в країнах ЄС дуже мало досліджено та описано ефект застосування імунокастрації для свинок, тому ми вважаємо, що дане питання $є$ актуальним, та потребує ретельного вивчення.

Мета. Враховуючи те що питання імунокастрації свинок не достатньо вивчене, метою нашої роботи було дослідити вплив імунної кастрації самок свиней на їх відгодівельні якості.

Матеріали та методи дослідження. Для досягнення поставленої мети нами з серпня по грудень місяць 2020 року на базі цеху відгодівлі № 3 «НВП «Глобинський свинокомплекс» було проведено дослідження по вивченню відгодівельних якостей імунокастрованих свинок. Відповідно до схеми досліду, яка представлена у таблиці 1 за методом груп аналогів було сфрормовано дві групи свинок отриманих від помісних свиноматок ірландського ландраса та ірландського йоркшира і кнурів синтетичної лінії Maxgro.

Таблиця 1

Схема досліду

\begin{tabular}{|l|c|c|c|}
\hline \multicolumn{1}{|c|}{ Група тварин } & Кількість голів в групі & Вік при постановці/ контрольному зважуванні, днів & Спосіб кастрації \\
\hline I (контрольна) & 220 & $70 / 72$ & некастровані \\
\hline II (дослідна) & 220 & $70 / 72$ & імунокастровані \\
\hline
\end{tabular}

Кожна група тварин налічувала 220 голів, яких було розміщенно в сусідніх станках по 55 голів в кожному, з нормою площі 0,75 м² на одну голову, на повністю щілинній бетонній підлозі. Мікроклімат в свинарнику підтримувався за допомогою системи вентиляції негативного тиску фірми Big Dutchaman, систем автоматичного зрошування та опалення. Напування здійснювалось за допомогою шести автонапувалок ніпельного типу, на один станок. Видалення гною за допомогою вакуумного-самопливної системи періодичної дії. Годівля свиней обох груп здійснювалась рідкими кормовими сумішами на основі повнораціонних комбікормів власного виробництва. Приготування рідкої суміші та її роздавання проводилась за допомогою кормової кухні австрійської фірми Veda. Годівля свинок була збалансованою та повноцінною в мультифазному режимі такими комбікормами: до маси 30 кг - Гровер 15-30; до маси 60 кг - Гровер 30-60; до маси 90 кг Фінішер 60-90; після 90 кг - Фінішер 90-130

Контрольних та дослідних свинок поставили на відгодівлю у віці 70 діб. Всі тварини на другий день після постановки були індивідуально зважені та ідентифіковані різнокольоровими бирками з індивідуальними номерами.

Тваринам дослідної групи у віці 112 днів було введено вакцину Improvac фірми Зоетіс Україна з розрахунку 2 мл на голову, та проведено ревакцинацію цією ж вакциною у віці 148 днів в такій же дозі.

Під час дослідження враховувалась кількість з'їденого корму на кожен станок, за допомогою комп'ютерних установок кормової кухні Veda, та проводився щоденний облік загального стану тварин та їх вибуття з зазначенням їх віку, маси та причини. Впродовж досліджень всі ветеринарні та технологічні процедури були ідентичні для обох груп. По закінченню терміну відгодівлі всі тварини були індивідуально зважені, на основі чого було проведено розрахунки інтенсивності росту, середньодобове споживання та оплати корму. За результатами дослідження було розраховано індекс відгодівельних якостей за формулою М.Д. Березовського [1]:

$$
\mathrm{I}=\mathrm{A}^{2} /\left(\mathrm{B}^{*} \mathrm{C}\right)
$$

де: $\quad$ A - валовий приріст за період відгодівлі, кг;

В - кількість діб відгодівлі, днів;

C - витрати корму на 1 кг приросту, корм.од.

Отримані результати досліду були обраховані біометрично за допомогою прикладних програм Microsoft Office Excel.

Також, з метою визначення сили впливу кастрації свинок було проведено однофакторний дисперсійний аналіз.

Результати дослідження та обговорення. Аналізуючи отримані результати дослідження можна констатувати, що загалом по всім відгодівельним показникам тварини дослідної групи (імунокастрованих свинок) переважали аналогів контрольної групи (некастрованих свинок). Так з таблиці 2 бачимо, що різниця середньої живої маси свинок при постановці на відгодівлю між групами була не значною. 
Таблиця 2

Відгодівельні показники

\begin{tabular}{|l|c|c|}
\hline \multicolumn{1}{|c|}{ Показник } & $\begin{array}{c}\text { I контрольна група } \\
\text { (некастровані свинки) }\end{array}$ & $\begin{array}{c}\text { I дослідна група } \\
\text { (імунокастровані свинки) }\end{array}$ \\
\hline Середня жива маса при постановці на відгодівлю, кг & $25,68 \pm 0,30$ & $25,82 \pm 0,26$ \\
\hline Середня жива маса при знятті з відгодівлі, кг & $119,11 \pm 0,74$ & $125,33 \pm 0,81^{* * *}$ \\
\hline Тривалість відгодівлі, діб & 106 & 106 \\
\hline Вік при знятті з відгодівлі, діб & 178 & 178 \\
\hline Абсолютний приріст, кг & $92,43 \pm 0,70$ & $99,01 \pm 0,88^{* * *}$ \\
\hline Середньодобовий приріст, г & $871,95 \pm 6,57$ & $934,01 \pm 8,34^{* * *}$ \\
\hline Відносний приріст, \% & $126,87 \pm 0,69$ & $131,07 \pm 0,79$ \\
\hline Вік досягнення живої маси 120 кг, діб & $180,3 \pm 0,95$ & $173,55 \pm 0,89$ \\
\hline Витрати корму на 1 кг приросту, кг & 2,51 & 2,45 \\
\hline Середньодобове споживання корму, кг/гол & 2,18 & 2,26 \\
\hline Індекс відгодівельних якостей, балів & 32,9 & 37,3 \\
\hline
\end{tabular}

Примітка : "** $(p<0,001)$

Середньодобове споживання корму свинок дослідної групи виявилось на 0,08 кг/гол, або на 3,54\% більшим порівняно зі свинками контрольної групи. На наш погляд це пов'язано з тим, що некастровані свинки приходячи в статеву охоту, та в цей час на фоні гормональних змін в організмі споживали менше корму. В свою чергу імунокастровані свинки не приходили в статеву охоту, що ймовірно й призвело до збільшення середньодобового споживання корму, та в подальшому мало позитивний вплив на інші відгодівельні показники свинок.

Необхідно зазначити, що тварини дослідної групи відрізнялись досить високою інтенсивністю росту. Вони мали вищі показники абсолютного приросту на 6,58 кг, або на $6,65 \%$ (р<0,001), та середньодобового приросту на 62,06 г або на $6,64 \%$ ( $p<0,001)$. Вищий показник відносного приросту також спостерігався у імуннокастрованих свинок, а його різниця між тваринами дослідної та контрольної групи склала $4,20 \%(p<0,001)$.

При завершенні відгодівлі у віці 178 діб імунокастровані свинки мали середню живу масу 125,33 кг, а некастровані виявились вірогідно на 6,22 кг або на 4,96\% легшими в порівнянні $з$ тваринами дослідної групи ( $p<0,001)$. Це насамперед пов'язано з середньодобовим споживанням корму, оскільки імунокастровані свинки більше споживали корму, тому їх прирости та відповідно середня жива маса при знятті з відгодівлі виявились значно вищими.

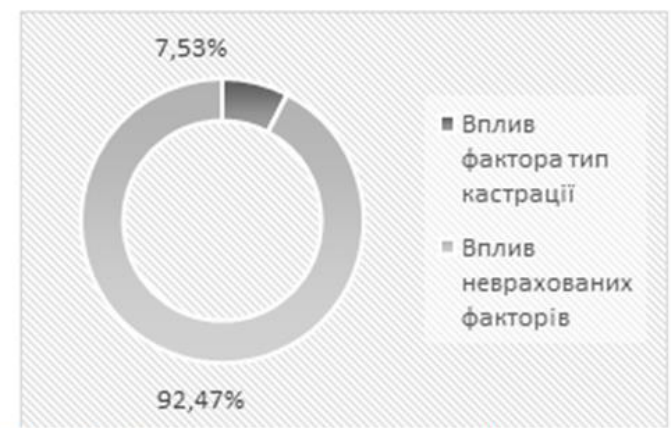

Рис.1. Сила впливу кастрації свинок на ix середню живу масу при знятті з відгодівлі
Нами було визначено вік досягнення живої маси 120 кг для обох груп, в результаті встановлено, що імунокастровані свинки на 6,75 днів раніше досягавали живої маси 120 кг, що є більш економічно і технологічно вигідно для господарства.

Витрати корму на одиницю приросту живої маси один з важливих показників, від якого залежить собівартість свинини, а також ефективність цієї галузі. Кращу конверсію корму мали свинки дослідної групи, яка склала 2,45 кг, що на 0,06 кг або на 2,39\% менше порівняно з тваринами контрольної групи.

За комплексним індексом відгодівельних якостей імунокастровані свинки мали вищий показник на 4,4 бали або на $11,8 \%$.

Методом однофакторного дисперсійного аналізу визначено силу впливу кастрації свинок на їх середню живу масу при знятті з відгодівлі. Відповідно до розрахунків вплив кастрації на середню живу масу при знятті з відгодівлі виявився статистично значним і склав $7,53 \%$ ( кастрації $32,08>$

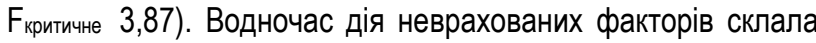
$92,47 \%$ (рис. 1).

Результат впливу кастрації свинок на їх абсолютний та середньодобовий приріст був статистично достовірним ( $\left.F_{\text {кастрації }} 48,26>F_{\text {критичне }} 3,87\right)$ в межах $10,92 \%$ та відповідно для середньодобового приросту 10,91\%. Тоді як невраховані фактори змінювали показники абсолютного приросту із силою 89,08\%, а середньодобового приросту - 89,09\%. (рис.2, 3)

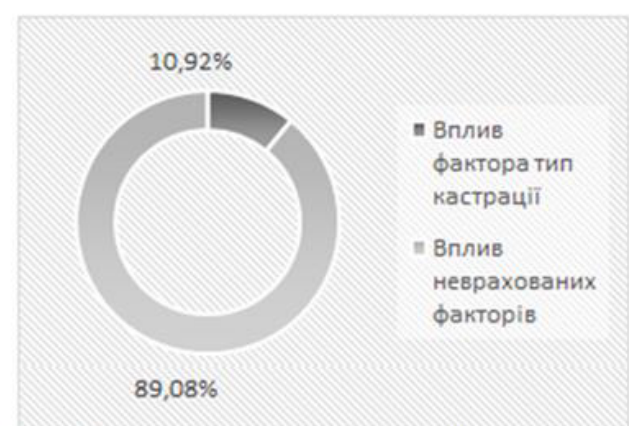

Рис.2. Сила впливу кастрації свинок на ïх абсолютний приріст при знятті з відгодівлі 
Однофакторний аналіз дав змогу виявити вплив кастрації свинок на відносний приріст, в результаті чого даний показник виявився статистично значним ( $F_{\text {кастрації }} 14125,17$ >

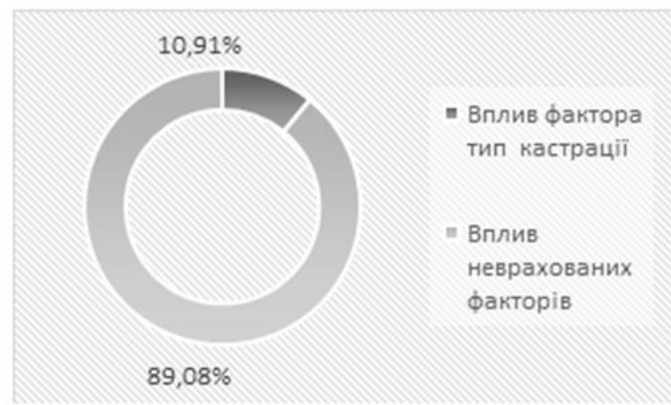

Рис.3. Сила впливу кастрації свинок на середньодобовий приріст, г

Дослідження впливу фактору кастрації свинок на вік досягнення живої маси 120 кг виявилось статистично досто-

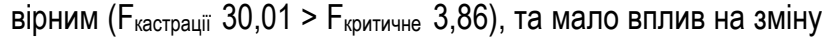
даного показника в межах $7,09 \%$. Тоді як невраховані фрактори мали зміни показника віку досягнення живої маси 120 кг з силою впливу 92,91\% (рис.5).

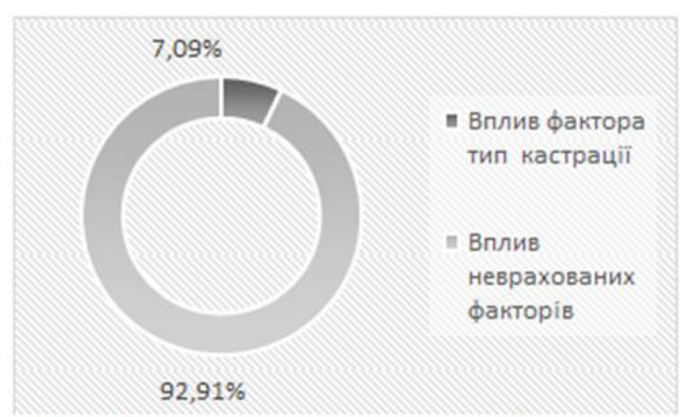

Рис.5. Сила впливу кастрації свинок

на вік досягнення живої маси $120 \mathrm{\kappa г}$

Результати наших досліджень стосовно збільшення середньодобового споживання корму імунокастрованими

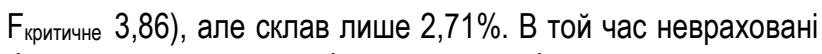
фактори спричинили зміну показника відносного приросту 3 силою впливу 97,29\% (рис.4).

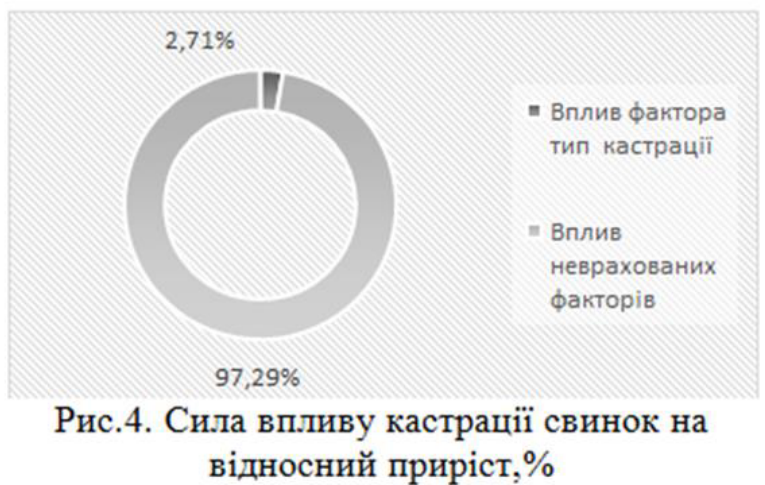

свинками співпадають з результатами досліджень Yongqiang Xue [6], але вони не узгоджуються з ії̈ даними стосовно інтенсивності росту та конверсії корму. Тому вважаємо за доцільно продовжити дослідження в даному напрямку

Висновки. 1. Встановлено що кращими відгодівельними якостями характеризувалися імунокастровані свинки. Вони перевищували своїх некастрованих аналогів за масою при знятті з відгодівлі на 6,22 кг або 4,96\% , за віком досягнення маси 120 кг на 6,75 днів (3,89\%), середньодобовими приростами під час відгодівлі на 62,1г або на 6,64\%. При цьому вони щодоби споживали на 0,08 кг/гол, або на 3,54\% більше корму, та мали на 0,06 кг (2,39\%) кращу його конверсію.

2. Відповідно до результатів однофакторного дисперсійного аналізу встановлено силу впливу кастрації свинок на їх відгодівельні показники, яка склала: на середню живу масу при зняті з відгодівлі 7,53\%, на абсолютний приріст 10,92\%, середньодобовий приріст 10,91\%, відносний приріст 2,71\% на вік досягнення живої маси 120 кг 7,09\%. Невраховані фрактори мали зміни відгодівельних показників з силою впливу відповідно 92,47\%, 89,08\%, 89,09\%, 97,29\%, 92,91\%

\section{Список використаної літератури:}

1.Березовский Н. Д. Селекционная работа с крупной белой породой свиней в Украине. Современные проблемы интенсиффикации производства свинины: мат. межд. конф. Ульяновск, 2007. Т.1. С. 29-33.

2.Повод М. Г., Кравченко О. І., Нечмілов В. М., Кліндухова І. М.. Відгодівельні якості хірургічних та імунологічних кастратів за різного типу годівлі та передзабійної живої маси годівлі. Вісник Сумського національного аграрного університету : науковий журнал. Сер. "Тваринниитво". Суми: СНАУ, 2018. - Bun. 7 (35).

3.Zamaratskaiaa G., Krøyer Rasmussenb M. Immunocastration of male pigs - situation today. Procedia food science volume 5, 2015, pp. 324-327.

4.Čandek-Potokar M., Škrlep M, , Zamaratskaia G, Immunocastration as alternative to surgical castration in pigs. In book: Theriogenology Publisher: InTech. 6 th. 2017. DOI: 10.5772/intechopen.68650.

5.Škrlep M., Šegula B., Zajec M, Kastelic M., Košorok S., Fazarinc Čandek - Potokar G., 2010. Effect of immunocastration (Improvac®) in fattening pigs i: growth performance, reproductive organs and malodorous compo. Slov Vet Res; 47 (2). pp. 57-64.

6.Batorek N., Čandek-Potokar M., Bonneau M., Van Milgen J. 2012. Meta-analysis of the effect of immunocastration on production performance, reproductive organs and boar taint compounds in pigs. Published online by Cambridge University Press. The International Journal of Animal Biosciences. 6(8):1330-8. DOI: 10.1017/S1751731112000146.

7.Yongqiang Xue, Weijiang Zheng, Feng Zhang, Shiting Rao, Zhifeng Peng and Wen Yao. Effect of immunocastration on growth performance, gonadal development and carcass and meat qualityof SuHuai female pigs. Animal production science. 2019. 59. pp.794-800. DOl.org/10.1071/AN16733.

8.Hogs, pigs, and pork: veb-sait. URL: https://swine.extension.org/what-is-immunocastration-and-how-does-it-work/ [Aaccessed 08.12 .2020$]$ 


\section{References:}

1.Berezovsky, N. D., 2007. Selektsyonnaia rabota s krupnoi beloi porodoi svynei v Ukrayne [Selection work with a large white breed of pigs in Ukraine]. Sovremennыe problemb yntensyfykatsyy proyzvodstva svynynbl: mat. mezhd. konf. Ulianovsk, vol.1, pp. 29-33.

2.Povod M. G, Kravchenko O. I, Nechmilov V. M and Klindukhov I. M., 2018. Vidhodivelni yakosti khirurhichnykh ta imunolohichnykh kastrativ za riznoho typu hodivli ta peredzabiinoi zhyvoi masy hodivli. [Feeding qualities of surgical and immunological castrates for different types of feeding and pre-slaughter live weight of feeding]. Visnyk Sumskoho natsionalnoho ahrarnoho universytetu : naukovyi zhurnal. Ser. "Tvarynnytstvo". Sumy: SNAU, vol. 7 (35). pp. 356-367.

3.Zamaratskaiaa G. and Krøyer Rasmussenb M., 2015. Immunocastration of male pigs - situation today. Procedia food science volume 5 , , pp. 324-327.

4.Čandek-Potokar M., Škrlep M/ and Zamaratskaia G.. 2017. Immunocastration as alternative to surgical castration in pigs. In book: Theriogenology Publisher: InTech. 6 th. DOI: 10.5772/intechopen.68650.

5.Škrlep M., Šegula B., Zajec M, Kastelic M., Košorok S. and Fazarinc Čandek - Potokar G., 2010. Effect of immunocastration (Improvac®) in fattening pigs i: growth performance, reproductive organs and malodorous compo. Slov Vet Res; 47 (2). pp. $57-64$.

6.Batorek N., Čandek-Potokar M., Bonneau M., and Van Milgen J., 2012. Meta-analysis of the effect of immunocastration on production performance, reproductive organs and boar taint compounds in pigs. Published online by Cambridge University Press. The International Journal of Animal Biosciences. 6(8):1330-8. DOI: 10.1017/S1751731112000146.

7.Yongqiang Xue, Weijiang Zheng, Feng Zhang, Shiting Rao, Zhifeng Peng and Wen Yao. Effect of immunocastration on growth performance, gonadal development and carcass and meat qualityof SuHuai female pigs. Animal production science, 2019. 59, pp.794-800. DOl.org/10.1071/AN16733.

8.Hogs, pigs, and pork: veb-sait. URL: https://swine.extension.org/what-is-immunocastration-and-how-does-it-work/ [Aaccessed 08.12 .2020$]$. Ukraine)

Andrieieva Diana Mykolaivna, graduate student special.204 «TVPPLP», Mykolayiv National Agrarian University (Mykolaiv,

Povod Mykola Hryhorovych, Doctor of Agricultural Sciences, Professor, Sumy National Agrarian University (Sumy, Ukraine)

Fatteting qualities of immunocastrated and uncastrated pigs

The article presents the research results of the study of fatteting qualities of immunocastrated and non-castrated pigs which were received/obtained from local sows of Irish Landrace, Irish Yorkshire and synthetic line Maxro boars in the conditions of OOO(LLC) NPP(research and production enterprise) Globinsky pig-breeding complex, fatteting workshop №3. To carry out the study, two groups of pigs were formed, the average live weight of which was in the range of $25.68-25.82 \mathrm{~kg}$, with an error of 0,30-0,26 kg. It was found that during the fattening period the immunocastrated pigs, in contrast to the non-castrated pigs, had a large average live weight at removal from fattening by $4,96 \%$. They were characterized by $6.65 \%$ and $6.64 \%$ higher absolute and average daily growth rates. The relative gain of immunocastrated pigs was higher by $4,20 \%$ (d.<0,001). Immunocastrated pigs daily consumed more feed by $3,54 \%$ which led to the achievement of their live weight of $120 \mathrm{~kg}$ by $3.89 \%$ faster while the payment for feed by increments was better by 2,39\% as compared with non-castrated pigs. The index of a comprehensive assessment of the feeding qualities of immunocastrated animals was higher by 4.4 points or $11.8 \%$ compared to their non-castrated counterparts. Using/With the help of one-way analysis of variance, the strength of the influence of the type of castration of gilts on their fattening indicators was established. Significant influence of the type of pigs castration for fattening indicators such as average live weight at removal from fattening at the level of $7,53 \%$,absolute increase of $10,92 \%$, average daily gain of $10,91 \%$ and the age of reaching a live weight of $120 \mathrm{~kg}$ at $7,09 \%$ were defined. The strength of the influence of the type of castration of pigs on the relative gain was only $2.71 \%$. Research results have shown that the use of immune castration of pigs has a significant impact and increases their feeding performance/indicators.

Key words: piggy, growth/increase, immune castration, fattening, feed conversion, feed intake.

Дата надходження до редакції: 12.10.2020 р. 